\title{
The Effect of Complementary Vitamin D on Sputum Conversion in Pulmonary TB Patients
}

\author{
Nita Andriani Lubis \\ Department of Health Analysis, School of Health Polytechnics Medan, North Sumatera
}

\begin{abstract}
Background: Pulmonary TB is one of the most important health problems in Indonesia. The number of pulmonary TB patients ranked second after India. Vitamin D has a complex effect in the immune system. One of the effects of vitamin D is to stimulate the production of Cathelicidin which increases macrophage phagocytosis. This study aimed to analyze the effect of complementary vitamin D on sputum conversion in pulmonary tuberculosis patients.

Subjects and Method: This study was a randomized controlled trial conducted at several health centers in Deli Serdang, North Sumatera, from November 2015 to June 2016. A total sample of 80 patients with positive acid-resistant bacilli (BTA) was selected for this study by consecutive sampling. The sample was allocated randomly into two groups: (1) TB drug group $+2.5 \mathrm{mg}$ vitamin D; (2) TB drug group + placebo. The dependent variable was sputum conversion. The independent variable was complementary vitamin D. Pre and post vitamin D levels were examined by ELISA technique. Sputum conversion was examined by TB laboratory worker at the health center where patients received TB drug treatment. Difference in percent of sputum conversion between the two groups was tested by chi-square test. Difference in mean of sputum conversion time between the two groups was tested by t-test.

Results: The mean serum vitamin D level in the intervention group (62.05 \pm 22.08$)$ was higher than the control group $(28.56 \pm 7.48)$ after the intervention, and it was statistically significant ( $\mathrm{p}<0.001)$. After 56 days, all subjects in the vitamin D group experienced sputum conversion (100\%) with a median sputum conversion time of 28 days, whereas $90 \%$ of subjects in the placebo group experienced sputum conversion with a median sputum conversion time of 48 days $(\mathrm{p}=$ 0.002).
\end{abstract}

Conclusion: Adding vitamin D to anti-TB drug treatment effectively improves and accelerates sputum conversion of patients with tuberculosis acid-fast bacilli smear positive.

Keywords: Vitamin D, sputum conversion, pulmonary tuberculosis

\section{Correspondence:}

Nita Andriani Lubis. Department of Health Analysis, School of Health Polytechnics Medan, North Sumatera. Jl. William Iskandar Pasar V Barat No. 6 Medan 20137, North Sumatera, Indonesia. Email: taufik.abay.mumtaz@gmail.com.

\footnotetext{
BACKGROUND

Tuberculosis (TB) is a major public health threat. According to WHO, Indonesia ranked second of $\mathrm{TB}$ burden worldwide (WHO, 2014). Genetic factor is a factor that may explain why some people are more resistant to Mycobacterium tuberculosis infection than others. Environmental and genetic factors determine the development of clinical disease in people infected with M. tuberculosis (Rosenberg et al., 2007).
}

Vitamin is an essential organic substance for a human body. Vitamin D and its metabolites are essential in the body's physiological processes, such as bone control and calcium homeostasis (Selvaraj, 2011).

Vitamin D especially vitamin D metabolites (1.25 (OH) 2D3) stimulates the production of anti-bacterial peptides such as Cathelicidin and Defensin (Rashedi et al, 2015; Dini and Baianchi, 2012). Previous 
study has shown the important role of vitamin $\mathrm{D}$ in regulating the immune system through its binding with Vitamin D Receptor (VDR) (Junaid et al, 2016; Martineau et al, 2012; Selvaraj et al, 2008).

TB patients had low vitamin D level. Several studies have found that vitamin D level indicates the body's defense ability against M. tuberculosis infection. It is known that vitamin $\mathrm{D}$ activated metabolite 1.25-dihydroxy vitamin $\mathrm{D} 3(1.25 \mathrm{D} 3)$ can enhance natural immune regulation against Mycobacterium tuberculosis (Martineau et al, 2011, Haussler et al, 2013; Simon et al, 2013; Coussens et al, 2012).

The effect of vitamin D on TB therapy has been extensively studied in Cipto Mangunkusumo Hospital, Jakarta, in Malang, and Wonosobo. The study showed that vitamin D therapy can enhance sputum conversion (Nursyam, 2006; Siswanto, 2009; Pratiwi, 2013).

This study aimed to determine the effect of vitamin $\mathrm{D}$ on smear sputum conversion in pulmonary tuberculosis patients in Deli Serdang District, North Sumatera.

\section{SUBJECTS AND METHOD \\ 1. Study design \\ This was a randomized controlled trial (RCT) conducted at community health centers in Deli Serdang District, North Sumatera, from November 2015 to June 2016.}

\section{Population and sample}

A total sample of 80 Tuberculosis patients was selected for this study. Critical inclusion of study subjects was newly diagnosed lung tuberculosis, positive sputum, minimum age 18 years, and BMI $\geq 18.5$. Exclusion criteria were HIV positive, taking immunopresive drugs, kidney failure and diabetes mellitus.
A total sample of 80 patients with positive acid-resistant bacilli (BTA) was selected for this study by consecutive sampling. The sample was allocated randomly into two groups: (1) TB drug group + $2.5 \mathrm{mg}$ vitamin D (intervention group); (2) TB drug group + placebo (control group). The intervention group received four doses of $2.5 \mathrm{mg}$ vitamin D3 (Bio-tech pharmaceutical, US) every two weeks (o, 14, 28, and 42 days) (Martineau et al, 2011).

\section{Study Variables}

The dependent variables were serum vitamin D level, percent and duration of sputum conversion. The independent variable was adding vitamin $\mathrm{D}$ on $\mathrm{TB}$ drug therapy.

Vitamin D status was categorized as deficient ( $<20 \mathrm{ng} / \mathrm{ml}$ ), insufficiency (20-30 $\mathrm{ng} / \mathrm{ml})$, and optimal $(\geq 30 \mathrm{ng} / \mathrm{ml}$ ) (Martineau et al, 2011; Junaid et al, 2016; Jolliffe et al, 2015).

\section{Study Procedure}

Before the intervention, blood samples were taken from all patients to check previtamin D levels with ELISA. Vitamin D and placebo were administered in 4 doses of 2.5 mg (bio-tech Pharmacal, US) with the time of administration of $0,14,28$, and 42 days. TB drug with or without vitamin $\mathrm{D}$ was given every 2 weeks. Patients were followed for two months and examined for sputum conversion every two weeks (14 days, 28 days, 42 days and 56 days). Sputum specimens were examined to determine the presence of Acid-Fast Bacilli (AFB) (Martineau et al., 201; Nursyam et al., 2006; Babb et al., 2007).

Sputum conversion checks were performed by medical laboratory technicians at the community health centers. Vitamin D level was measured using ELISA at the Integrated Laboratory Unit, Faculty of Medicine, University of North Sumatra, Medan. 


\section{Data analysis}

Difference in percent of sputum conversion between the two groups was tested by chisquare test. Difference in mean of sputum conversion time between the two groups was tested by t-test.

\section{Research ethics approval}

This study complied with the ethical standard set by the Declaration of the World Medical Association of Helsinki. It was approved by the Institutional Review Board of the Faculty of Medicine, University of North Sumatra, Ministry of Education and Culture of the Republic of Indonesia. All study subjects have provided written informed consent.

\section{RESULTS}

Table 1 described the characteristic of the study subjects. Anti-tuberculosis drugs

Table 1. Characteristic of the study subjects

\begin{tabular}{|c|c|c|c|}
\hline Variables & Vitamin D & Placebo & $\mathbf{p}$ \\
\hline \multicolumn{4}{|l|}{ Sex } \\
\hline - Male & $26(65 \%)$ & $27(68 \%)$ & 0.810 \\
\hline - Female & $14(35 \%)$ & $13(32 \%)$ & \\
\hline \multicolumn{4}{|l|}{ Occupation } \\
\hline - Employed & $23(58 \%)$ & $25(63 \%)$ & \\
\hline - Unemployed & $12(30 \%)$ & $13(32 \%)$ & 0.490 \\
\hline - Student & $5(12 \%)$ & $2(5 \%)$ & \\
\hline \multicolumn{4}{|l|}{ Baseline sputum smear } \\
\hline - $\quad+1$ 10-99 AFB/100 fields & $21(53 \%)$ & $8(20 \%)$ & \\
\hline$-\quad+2$ 1-10 $\mathrm{AFB} / 50$ fields & $9(22 \%)$ & $19(48 \%)$ & 0.007 \\
\hline$-+3>10 \mathrm{AFB} / 20$ fields & $10(25 \%)$ & $13(32 \%)$ & \\
\hline \multicolumn{4}{|l|}{ Vitamin D Status } \\
\hline - Deficient & $6(15 \%)$ & $9(22 \%)$ & \\
\hline - Insufficient & $11(27 \%)$ & $15(38 \%)$ & 0.290 \\
\hline - Optimal & $23(58 \%)$ & $16(40 \%)$ & \\
\hline Vitamin D Pre (ng/ml) & $31.78 \pm 9.45$ & $26.85 \pm 8.22$ & 0.290 \\
\hline Vitamin D Post (ng/ml) & $62.05 \pm 22.08$ & $28.56 \pm 7.48$ & $<0.001$ \\
\hline
\end{tabular}

Figure 1 showed that after 56 days, all subjects in the vitamin $\mathrm{D}$ group experienced a conversion (100\%) with a median sputum conversion time of 28 days. $90 \%$ of subjects were given in accordance with the DOTS program category I: $2 \mathrm{RHZE} / 4 \mathrm{RH}$.

Table 1 showed that the mean difference of serum Vitamin D level before intervention was comparable between the intervention (31.78 \pm 9.45$)$ and the control group (26.85 \pm 8.22$)$, and it was statistically non-significant $(\mathrm{p}=0.290)$. It means that randomization had successfully allocated the baseline serum vitamin $D$ level evenly between the two groups.

Table 1 also showed that the mean serum vitamin $\mathrm{D}$ level in the intervention group $(62.05 \pm 22.08)$ was higher than the control group (28.56 \pm 7.48$)$ after the intervention, and it was statistically significant $(\mathrm{p}<0.001)$. It means that the administration of vitamin D effectively increased the serum vitamin $\mathrm{D}$ level in the intervention group. 
Indonesian Journal of Medicine (2017), 2(3): 169-174

https://doi.org/10.26911/theijmed.2017.02.03.04

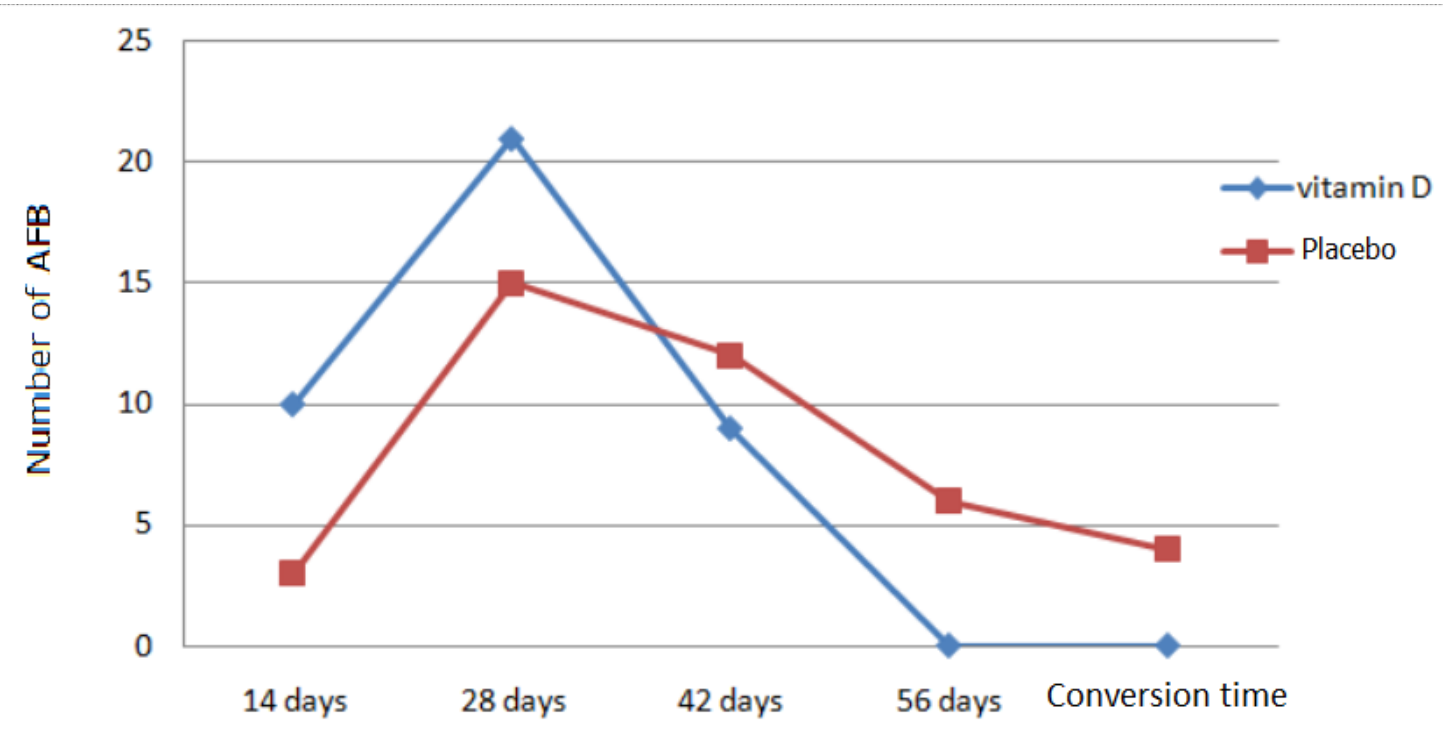

Figure 1. Sputum smear conversion time and number of positive Acid-Fast Bacilli (AFB) in the intervention and control group

\section{DISCUSSION}

This study indicated that the vitamin $\mathrm{D}$ serum level in the vitamin D group was higher than that in the control group. This increase in vitamin $\mathrm{D}$ level came from the high dose of vitamin D provided and from food consumed. Vitamin D has a specific role in the natural immune system as an agent that fights against infection. Specifically, the active metabolite of vitamin $\mathrm{D}$ will stimulate macrophages through Cathelicidin protein in $\mathrm{M}$. tuberculosis phagocytosis.

The present study also found that the percent of sputum conversion was higher in the vitamin $\mathrm{D}$ group than in that control group. The sputum conversion time was also shorter in the vitamin D group than in the control group. These findings indicate that adding vitamin $\mathrm{D}$ to anti-TB drug treatment effectively improves and accelerates sputum conversion of patients with tuberculosis acid-fast bacilli smear positive. These findings are consistent with previous studies in Indonesia and in England (Coussens et al., 2012; Nursyam et al., 2009; Martineau et al., 2016).
There were 4 subjects who did not undergo conversion in the control group. The initial AFB status of all four subjects was +3 that took longer for conversion. One possibility of this longer conversion is due to MDR TB. Parikh et al. (2012) state that patients with higher number of acidresistant TB bacilli $(+3)$ has a higher risk of developing a drug-resistant mutant than those with lower number of acid-resistant bacilli ( +2 and +1$)$.

This study showed that complementary vitamin D effectively increase the sputum conversion and shorten the sputum conversion time. Therefore, provision of vitamin $\mathrm{D}$ in patients with $\mathrm{TB}$ is highly recommended as one way to break the chain of transmission of infectious germs TB. Supplementation of vitamin D can improve the patient's immune system by encouraging the production of cataracts that play a role in combating tuberculosis germs (Martineau et al, 2011; Chen et al, 2013; Lee \& Song, 2015).

Micronutrients as additional immunotherapy are potentially developed and become a medical concern because scientific evidence of anti-microbacterial activity 
specific to vitamin D3 in macrophages has been overwhelming. This needs to be considered as an additional therapy in TB cases (Nursyam et al, 2009, Martineau et al, 2011; Coussens et al, 2012).

This study concludes that adding vitamin $\mathrm{D}$ to anti-TB drug treatment effecttively improves and accelerates sputum conversion of patients with tuberculosis acid-fast bacilli smear positive. It is suggested that supplementary Vitamin D be added to anti-TB drug treatment to enhance its effectiveness.

$\frac{\text { REFERENCE }}{\text { Babb C, Merwe L, Bayers N, Pheiffer C, }}$ Walzl G, Duncan K, Hendel P, Hoal, EG (2007). Vitamin D Receptor Gene Polymorphisms and Sputum Conversion Tine in Pulmonary Tuberculosis Patients. Tuberculosis journal. 87 (-), 95-130.

Chen C, Liu Q, Zhu L, Yang H, Lu W (2013). Reseptor vitamin D Gene Polymorphisms on the Risk of Tuberkulosis, a Meta-Analysis of 29 Case-Control Studies. Plos One Journal. 8 (12), e83843.

Coussens AK, Wilkinson RJ, Hanifa Y, Nikolayevsky V, Elkington PT, Islam K, Timms PM, Venton TR, Bethamley GH, Pecke GE, Mein CE, Rosun LB, Nuamah R, Yang DB, Drobniewski FA, Giffith (2012). Vitamin D Accelerates Resolution of Inflamatory Respons During Tuberculosis Treathment,. PNAS. 109: 15449-15454.

Dini C, Bianchi A. (2012). The potential role of vitamin $\mathrm{D}$ for prevention and treatment of tuberkulosis and infectious diseases. Ann Ist Super Sanità. 48: 319-327.

Donald PR, Marais BJ, Barry CE (2010). Age and the epidemiology and patho- genesis of tuberculosis. Lancet. 375, 1852-1854.

Haussler MR, Haussler CA, Bartik L, Whitfield GK, Hsieh JC, Slater S, Jurutka PW (2008). Reseptor vitamin D: Molecular Signalling and Actions of Nutritional Ligands in Disease Prevention. Nutrition Reviews. 66, S98-S112.

Jolliffe DA, Walton RT, Criffiths CJ, Martineau AR (2015). Single Nucleotide Polymorphisms In The Vitamin D Pathway Associating With Circulating Concentrations of Vitamin D Metabolites And Non-Skeletal Health Outcomes: Review of Genetic Assoiatio, Studies. Journal of Steroid Biochemistry and Molecular Biology. 11: 4587.

Junaid K, Rahman A, Saeed T, Jolliffe DA, Wood K, Martineau AR (2016). Vitamin D Deficiency Associates with Susceptibility to Tuberculosis in Pakistan but Polymorphisms in VDR, DBP and CYP2R1 do not. BMC Pulmonary Medicine. 16: 73.

Kementerian Kesehatan Republik Indonesia (2014). Profil Kesehatan Indonesia Tahun 2013, Jakarta.

Lee YH, Song GG (2015). Vitamin D Receptor Gene FokI, TaqI, BsmI and ApaI Polymorphsms and Susceptibility to Pulmonary Tuberculosis: a Meta Analysis. Genetics and Molecular Research. 14 (3), 9118-9128.

Martineau AR, Timms PM, Bothamley GH, Hanifa Y, Claxton K, Claxton AP, Packe GE, Gillon JCM, Darmalingam M, Davidson RN, Milburn HJ, Baker LV, Barke LD, Woodward NJ, Venton TR, Barn (2011). High-dose vitamin D3 during intensive-phase antimicrobial treatment of pulmonary tuberkulosis: a double-blind randomised controlled trial. Lancet. 50, 242-377. 
Indonesian Journal of Medicine (2017), 2(3): 169-174

https://doi.org/10.26911/theijmed.2017.02.03.04

Nursyam EW, Amin Z, Rumende CM (2006). The Effect of Vitamin D as Suplementary Treatment in Patiens with Moderately Advanced Pulmonary Tuberculosis Lession. Acta Medica Indonesia Journal International Medicine. 38, 3-5.

Parikh R, Nataraj G, Kanade S, Khatri V, Mehta P (2012). Time to Sputum Conversion in Smear Positive Pulmonary TB Patients on Category I DOTS and Factors Delaying it. JAPI. 60, 22-26.

Rashedi J, Asgharzadeh M, Moaddab SR, Sahebi L, Khalili M, Mazani M, Abdolalizadeh J. (2015). Vitamin D Receptor Gene Polymorphism and Vitamin D Plasma Concentration: Correlation with Susceptibility to Tuberkulosis. Advanced Parmaceutical Bulletin. 5: 1-5.

Rosenberg IH(2007). Challenges and opportunities in the translation of the science of vitamins. American Journal Clinical Nutrition. 85 (-), 325S-327S.

Selvaraj P, Vidyarani M, Jawahar MS, Algarasu K, Anand SP, Narayanan PR (2008). Regulatory role of promoter and 3' UTR variants of reseptor vita- min D gene on cytokine response in pulmonary tuberculosis. J Clin Immunol. 28, 306-313.

Selvaraj P (2011). Vitamines and Hormones. Elsevier Inc. India.

Simon GA, Georgiana DC, Nicoleta C, Daniela PM, Traian S, Veronica S (2013). ApaI and TaqI polymorphisms of RVD (reseptor vitamin D) gene in association with susceptibility to tuberkulosis in the Romanian population. Romanian Biotechnological Letters.18: 7956-7962.

Sinaga BYM, Amin M, Siregar Y (2014). Pulmonary Tuberculosis in an Indonesian Batak-ethnic Population. The Indonesian Journal of Internal Medicine. 46 (4): 275-282.

Siswanto, Sumarno, Yani J, Widayanti OA, Muktiati NS (2009). Pengobatan Suportif Vitamin D Mempercepat Konversi Sputum dan Perbaikan Gambaran Radiologis Pasien Tuberkulosis. Jurnal Kedokteran Brawijaya. 1: 128-132.

WHO (2014) Global Tuberkulosis Report 2014, Minimum graphics, France. 